JPKM : Jurnal Pengabdian Kesehatan Masyarakat
http://ejurnal.ung.ac.id/index.php/jpkm/index
https://doi.org/10.37905/.VxIx
E-ISSN 2774-3519

\title{
PELATIHAN PEMBUATAN HAND SANITIZER ALAMI SEBAGAI IMPLEMENTASI PERILAKU HIDUP BERSIH DAN SEHAT DI MASA PANDEMI COVID-19
}

\section{TRAINING ON MAKING NATURAL HAND SANITIZERS AS AN IMPLEMENTATION OF CLEAN AND HEALTHY LIVING BEHAVIORS DURING THE COVID-19 PANDEMIC}

\author{
Tri Septian Maksum \\ Program Studi Kesehatan Masyarakat, Universitas Negeri Gorontalo, \\ Indonesia \\ email : triseptian@ung.ac.id
}

\begin{abstract}
Abstrak
COVID-19 merupakan penyakit yang disebabkan oleh jenis coronavirus baru (SARS-CoV-2), yang saat ini telah menjadi masalah kesehatan global seiring belum dirilisnya vaksin. Kasus COVID-19 di Provinsi Gorontalo khususnya di Kabupaten Gorontalo Utara belum mengalami penurunan, sehingga upaya terbaik yang dapat dilakukan saat ini adalah menerapkan Perilaku Hidup Bersih dan Sehat (PHBS). Kegiatan pengabdian ini dilaksanakan di Desa Tudi Kecamatan Monano Kabupaten Gorontalo Utara, dengan tujuan untuk memberdayakan masyarakat dalam mengembangkan potensi desanya melalui kegiatan pelatihan pembuatan hand sanitizer alami. Target yang hendak dicapai yakni meningkatnya pengetahuan dan partisipasi masyarakat dalam mengimplementasikan upaya PHBS di masa pandemi COVID-19. Kegiatan ini diawali dengan tahap persiapan dan pembekalan, dilanjutkan dengan pelaksanaannya di lapangan yang dilakukan secara offline. Hasil pelaksanaan kegiatan yaitu masyarakat telah memiliki keterampilan dalam membuat hand sanitizer alami, sehingga menjadi upaya dalam mengontrol penyebaran virus COVID-19. Disarankan agar kegiatan ini menjadi cikal bakal usaha kreatif masyarakat di Desa Tudi dalam menyikapi pandemi COVID-19, sehingga dapat meningkatkan ekonomi masyarakat akibat terdampak COVID-19.
\end{abstract}

Kata Kunci : COVID-19; PHBS; Hand Sanitizer

\section{Abstract}

COVID-19 is a disease caused by a new type of coronavirus (SARS-CoV2), which currently has become a global health problem as a vaccine has not been released. The cases of COVID-19 in Gorontalo Province, especially in North Gorontalo District, have not decreased, so the best effort that can be done now is to implement Clean and Healthy Behavior (PHBS). This service activity was carried out in Tudi Village, Monano District, North Gorontalo District, with

Received: October $30^{\text {th }}, 2020 ; 1^{\star}$ Revised November $5^{\text {th }}, 2020 ; 2^{\text {nd }}$ Revised November $9^{\text {th }}, 2020$; Accepted for Publication: November $9^{\text {th }}, 2020$ 
the aim of empowering the community to develop the potential of their village through training activities for making natural hand sanitizers. The target to be achieved is to increase public knowledge and participation in implementing PHBS efforts during the COVID-19 pandemic. This activity begins with the preparation and debriefing stages, followed by its implementation in the field which is carried out offline. The result of the implementation of activities is that the community has the skills to make natural hand sanitizers, so that it is an effort to control the spread of the COVID-19 virus. It is recommended that this activity be the forerunner of the community's creative efforts in Tudi Village in responding to the COVID-19 pandemic, so that it can improve the community's economy due to the impact of COVID-19.

Keywords: COVID-19; PHBS; Hand Sanitizer

(C) 2020 Universitas Negeri Gorontalo Under the license CC BY-SA 4.0

\section{PENDAHULUAN}

Coronavirus Diseases 2019 (COVID-19) adalah suatu penyakit yang disebabkan oleh strain coronavirus baru, yakni SARS-CoV-2 yang muncul di Wuhan, Hubei, Cina pada Desember 2019. Penyakit ini awalnya dikenal dengan nama 2019 novel coronavirus (2019nCoV) (1), kemudian diresmikan oleh WHO pada 11 Februari 2020 dengan sebutan COVID-

19 (2). Status penyakit ini beralih menjadi pandemi pada 11 Maret 2020 (3). Pandemi COVID-19 sampai dengan 20
April 2020 telah menyebar ke 213 negara/territorial (4).

COVID-19 memiliki gejala yang mirip dengan influenza (5), akan tetapi virus ini lebih cepat berkembang sehingga akibatnya menimbulkan infeksi yang lebih parah dan berdampak pada gagal organ (6). Tanda dan gejala umum COVID-19 meliputi demam, sakit kepala, dan batuk. Penularan terjadi melalui percikan air saat batuk atau bersin (droplet) dan virus ini menginfeksi manusia ketika droplet tersebut dihirup 
atau disentuh, sehingga akan menempel pada selaput lendir mata, mulut, hidung, dan saluran napas termasuk paruparu (7).

COVID-19 di Provinsi Gorontalo sampai dengan 11 Agustus 2020, adalah sejumlah 1617 kasus, yang terdistribusi pada 369 kasus dirawat, 1207 kasus sembuh, dan 41 kasus meninggal. Dari angka tersebut, khusus wilayah Kabupaten Gorontalo Utara total kasus yang dilaporkan sebanyak 119, 40 kasus dirawat, 75 kasus sembuh, dan meninggal 4 kasus (8). Menurut data tersebut, dapat dikatakan bahwa penularan masih terus berlangsung, dan belum ada indikasi kurva pandemi melandai. Oleh karena itu, upaya yang paling efektif dilakukan saat ini adalah mengimplementasikan Perilaku Hidup Bersih dan Sehat (PHBS) dan selalu menjalankan protokol kesehatan yang digaungkan oleh pemerintah, seperti memakai masker, mencuci tangan dengan sabun di air mengalir, dan menjaga jarak. Cuci tangan pakai sabun merupakan salah satu implementasi PHBS di rumah tangga (9). Namun, ada saat dimana kita sedang berpergian atau beraktivitas di luar rumah sehingga mengalami kesulitan mencari tempat untuk mencuci tangan. Sehingganya penggunaan hand sanitizer dapat menjadi solusi untuk membersihkan tangan dari kuman yang menempel (10).

\section{Berdasarkan}

permasalahan di atas, maka perlu untuk dilakukan kegiatan pengabdian kepada masyarakat tentang pelatihan pembuatan hand sanitizer alami sebagai implementasi perilaku hidup bersih dan sehat di masa 
pandemi COVID-19. Kegiatan pengabdian kepada masyarakat dilakukan di Desa Tudi Kecamatan Monano Kabupaten Gorontalo Utara, dengan tujuan untuk memberdayakan masyarakat dalam mengembangkan potensi desanya melalui kegiatan pelatihan pembuatan hand sanitizer alami.

\section{METODE PELAKSANAAN}

Kegiatan pengabdian kepada masyarakat ini diawali dengan tahap persiapan dan pembekalan, kemudian dilanjutkan dengan pelaksanaan kegiatan. Tahap persiapan dan pembekalan berupa penyiapan materi penyuluhan serta alat dan bahan yang digunakan untuk kegiatan pelatihan pembuatan hand sanitizer alami. Sementara untuk tahap pelaksanaan adalah sebagai berikut :
1) Observasi lapangan untuk menganalisis situasi yang dihadapi oleh masyarakat di Desa Tudi Kecamatan Monano Kabupaten Gorontalo Utara pada pandemi COVID-19

2) Persiapan program, meliputi penyusunan jadwal pelaksanaan kegiatan yang disepakati bersama masyarakat

3) Penyuluhan tentang implementasi PHBS yang dilakukan menggunakan metode ceramah yang dilanjutkan dengan sesi diskusi (tanya jawab) yang dilakukan secara offline

4) Pelatihan pembuatan hand sanitizer alami dari bahan ekstrak daun sirih $15 \%$ dan jeruk nipis 8\% yang juga dilakukan menggunakan metode offline, yaitu konvensional yang biasanya dilakukan pada setiap 
kegiatan dengan melakukan kegiatan secara langsung atau tatap muka.

Adapun alat dan bahan yang diperlukan dalam pembuatan hand sanitizer alami serta prosedur kerjanya adalah sebagai berikut :

1) Alat
a) Wadah
b) Timbangan
c) Kompor
d) Gunting
e) Panci
f) Saringan
g) Botol spray

2) Bahan
a) Air matang
b) Daun sirih

3) Prosedur kerja

a) Daun sirih dicuci dan ditiriskan, kemudian dipotong-potong hingga berukuran kecil.

b) Timbang $50 \mathrm{~g}$ daun sirih, kemudian masukkan ke dalam wadah.

c) Tambahkan air matang sekitar 150 - $200 \mathrm{ml}$ sampai daun sirih terendam.

d) Siapkan panci berisi air, kemudian letakkan di atas kompor dan nyalakan api kecil.

e) Masukkan wadah berisi daun sirih dan air ke dalam panci yang telah berisi air.

f) Panaskan pada suhu 90 ${ }^{\circ} \mathrm{C}$ selama $15-30$ menit.

g) Dinginkan rebusan daun sirih kemudian disaring.

h) Tambahkan air sampai $200 \mathrm{ml}$.

i) Untuk pembuatan 100 $\mathrm{ml}$ hand sanitizer : $40 \mathrm{ml}$ ekstrak daun sirih, 5 $10 \mathrm{ml}$ perasan jeruk nipis yg telah disaring, dan 50 - $45 \mathrm{ml}$ air 
matang, kemudian dicampur rata dan disaring. Setelah itu, masukkan ke dalam botol spray.

\section{HASIL DAN PEMBAHASAN}

Hasil observasi lapangan yang dilakukan menunjukkan bahwa masih kurangnya pengetahuan masyarakat terkait penggunaan bahan-bahan alami sebagai antiseptik (hand sanitizer), sehingga menjadi dasar dalam pelaksanaan kegiatan ini. Masyarakat belum mengetahui khasiat dari daun sirih dan jeruk nipis sebagai antiseptik, sehingga kedua jenis bahan alami tersebut hanya digunakan untuk kepentingan memasak dan/atau pengobatan saja.

Menjaga kebersihan adalah hal wajib yang harus selalu dilakukan oleh siapapun dan kapanpun. Salah satunya yang terpenting adalah menjaga kebersihan tangan, pasalnya tangan adalah bagian tubuh yang sangat rentan dan dapat dengan mudah menjadi tempat bersarangnya kuman penyebab penyakit. Dampak yang ditimbulkan akibat kebiasaan tidak menjaga kebersihan tangan bisa berskala ringan hingga berat akibat terserang kuman baik virus maupun bakteri, dan penyebarannya sendiri dapat terjadi lewat tangan, seperti flu, diare, hepatitis, H1N1 hingga penyakit COVID-19. Oleh karena itu, untuk mencegah berbagai infeksi tersebut, maka perlu untuk menjaga kebersihan tangan dengan rutin mencuci tangan menggunakan air bersih dan sabun selama kurang lebih 20 detik di bawah air yang mengalir. Namun, ada saat dimana kita keluar beraktivitas dan tidak menemukan sumber air bersih, 
penggunaan hand sanitizer bisa menjadi salah satu solusi untuk membersihkan tangan dari kuman yang menempel.

Pelatihan pembuatan hand sanitizer alami dilaksanakan di Sanggar Seni Desa Tudi, pada hari Sabtu 26 September 2020 pukul 10.00 WITA sampai dengan selesai. Bentuk pelaksanaannya tetap memperhatikan protokol kesehatan yang menjadi anjuran pemerintah, yakni sebelum masuk ruang pelatihan wajib mencuci tangan pakai sabun di air mengalir, menggunakan masker, dan melakukan physical distancing (menjaga jarak aman minimal 1 meter). Pelatihan pembuatan hand sanitizer alami ini diawali dengan kegiatan penyuluhan tentang implementasi PHBS yang dilakukan menggunakan metode ceramah dan dilanjutkan dengan sesi tanya jawab secara offline. Masyarakat yang hadir adalah perwakilan dari masing-masing dusun yang ada di Desa Tudi, untuk selanjutnya dapat menyebar-luaskan informasi yang diperoleh kepada masyarakat lain.

Pada pembuatan hand sanitizer ini menggunakan bahan alami yaitu dari ekstrak daun sirih $15 \%$ dan jeruk nipis $8 \%$, sehingga hand sanitizer ini sangat praktis dan dapat dibuat sendiri dengan tidak mengeluarkan biaya yang mahal. Khasiat ekstrak daun sirih $15 \%$ sama efektifnya dengan alkohol dalam membunuh kuman. Namun demikian, hand sanitizer ini tidak menggunakan alkohol dan bahan pengawet lainnya sehingga produk ini hanya mampu bertahan 4-7 hari. Keberhasilan kegiatan ini ditunjukkan dengan antusias 
masyarakat yang sangat tinggi dari awal hingga akhir kegiatan, dan olehnya itu masyarakat sudah mampu dan terampil secara mandiri dalam membuat hand sanitizer berbahan alami tersebut.

\section{KESIMPULAN}

Kegiatan pelatihan pembuatan hand sanitizer alami sebagai implementasi perilaku hidup bersih dan sehat di masa pandemi COVID-19, yang dilakukan di Desa Tudi Kecamatan Monano Kabupaten Gorontalo Utara secara keseluruhan sudah berjalan dengan lancar dan sesuai target yang diharapkan. Pengetahuan masyarakat tentang PHBS menjadi meningkat serta masyarakat menjadi terampil dalam mengembangkan potensi desanya secara mandiri di tengah pandemi COVID-19, sehingga menjadi salah satu upaya dalam mengontrol penyebaran virus COVID-19. Direkomendasikan agar kegiatan ini menjadi cikal bakal usaha kreatif masyarakat di Desa Tudi dalam menyikapi pandemi COVID-19, sehingga dapat meningkatkan pendapatan masyarakat.

\section{UCAPAN TERIMA KASIH}

Ucapan terima kasih penulis sampaikan kepada Pemerintah Desa Tudi Kecamatan Monano Kabupaten Gorontalo Utara yang telah bersedia menerima/memberikan izin dan memfasilitasi seluruh rangkaian kegiatan pengabdian kepada masyarakat.

\section{REFERENCES}

1. WHO. Naming the coronavirus disease (COVID-19) and the virus that causes it. https://www.who.int/emerg encies/diseases/novelcoro navirus-2019/technicalguidance/naming-the- 
coronavirus-disease-

(covid-2019)-and-the-

virus-that-causes-it. 2020.

2. WHO. WHO Director-

General's remarks at the media briefing on2019-

nCoV on 11 February 2020.

https://www.who.int/dg/sp

eeches/detail/who-

director-general-s-

remarksat-the-media-

briefing-on-2019-ncov-on-

11-february-2020. 2020.

3. WHO. WHO Director-

General's opening remarks at the media briefing on COVID-19 11 March 2020.

https://www.who.int/dg/sp

eeches/detail/who-

director-general-s-

openingremarks-at-the-

media-briefing-on-covid-

19---11-march-2020.

2020.

4. WHO. Coronavirus
(Covid-19).

https://who.sprinklr.com/\#.

2020.

5. Gorbalenya et al. The species Severe acute respiratory syndromerelated coronavirus: classifying 2019-nCoV and naming it SARS-CoV2. Nat Microbiol. 2020;5(2).

6. Amalia L, Irwan, Hiola F. Analisis Gejala Klinis dan Peningkatan Kekebalan Tubuh untuk Mencegah Penyakit

Covid-19. Jambura J Heal Sci Res. 2020;2(2):71-6.

7. Susilo A, Rumende CM, Pitoyo CW, Santoso WD, Yulianti M, Herikurniawan $\mathrm{H}$, et al. Coronavirus Disease 2019: Tinjauan Literatur Terkini. J Penyakit Dalam Indones. 2020;7(1):45-67.

8. Gorontalo DKP. Jumlah 
Terpapar Covid-19 Di Gorontalo.

https://dinkes.gorontalopr ov.go.id/covid-19/. 2020.

9. Ginting $R$, Huda $M$, Drifanda V, Affandi AR. Pemberdayaan

Masyarakat Desa Jungsemi di Masa Pandemi Covid 19 Melalui Pelatihan Pembuatan Hand Sanitizer dan Pelindung Wajah | Ginting I IJECS: Indonesian Journal of Empowerment and Community Services. IJECS Indones J Empower Community Serv [Internet]. 2020;1(1):20-7. Available from:

http://journal.univetbantar a.ac.id/index.php/ijecs/arti cle/view/780

10. Lin L, Lu L, Cao W, Li T. Hypothesis for potential pathogenesis of SARS-
CoV-2 infection-a review of immune changes in patients with viral pneumonia, emerging microbes \& infections. Emerg Microbes Infect. 2020;9(1):727-32. 